\title{
Zeytin Üreticilerinin Tarımsal Yayım Programlarına Katılımının Değerlendirilmesi
}

\author{
Bekir DEMIRTAŞ \\ Mustafa Kemal Üniversitesi, Ziraat Fakültesi, Tarım Ekonomisi Bölümü, Hatay, Türkiye \\ [ORCID ID: http://orcid.org/0000-0003-2603-3890] \\ Sorumlu yazar: bdemirtas@mku.edu.tr
}

Öz

Üreticilerin tarımsal yayım faaliyetlerine katııımını etkileyen faktörlerin belirlenmesini amaçlayan bu çalışmada, davranışsal niyetin analizinde Planlı Davranış Teorisi kullanıımıştır. Araştırmada, Akdeniz Bölgesindeki en büyük zeytin yetiştiriciliğinin yapıldığı Hatay ilindeki 175 üretici seçilmiştir. Üreticilerin yayım çalışmalarına katılma davranışı konusundaki niyetleri modelde ele alınmışıı. Ayrıca, üreticilerin kişisel özellikleri ile davranışsal niyetleri arasındaki ilişkiler incelenmiştir. Regresyon analizi sonuçlarına göre yayım çalışmalarına katılma niyeti üzerinde etkili olan en önemli değişken üreticilerin tutumu olduğu belirlenmiştir. Modeldeki değişkenler yayım çalışmalarına katılma niyetindeki varyansın \%51'ini açıklamaktadır. Üreticilerin kişisel özelliklerinden yaş ve eğitim seviyesi, deneyim süresi, yayım bilgisi ve zeytin bahçesi genişlikleri arasındaki farklılıklar önemli bulunmuştur. Üreticilerin tarımsal yayım çalışmalarına daha fazla katılmasında faydalılık ve uygunluk en çok dikkat edilmesi gereken konulardır.

Anahtar Kelimeler: Tarımsal yayım, Zeytin üreticileri, Çiftçi eğitimi, Planlı davranış teorisi, Hatay-Türkiye

\section{The Evaluation of Attendance in Agricultural Extension Programs of Olive Growers}

\begin{abstract}
In this research which aims to determine the factors that are affecting the participation of producers on agricultural extension activities, the Theory of Planned Behavior was used in the analysis of behavioral intention. Hatay has the largest olive production area in Mediterranean region, and 175 producers were chosen in the province of Hatay. The behavioral intentions of producers to participate in the extension program were considered in the model. Furthermore, the relationship between producer's characteristics and behavioral intentions were examined. According to regression analysis result, producer's attitude is the most important variable that effects intentions to participate in the study. Variables of the model explain $51 \%$ of the variance to participate in the extension programs. The personal characteristics of producers which are age, education degree, experience time, extension knowledge and olive orchard land differences were found significant. Usefulness and suitability should be the issues to be focused on more in order to encourage producers to involve in agricultural extension activities more.
\end{abstract}

Key Words: Agricultural extension, Olive growers, Farmer education, Theory of planned behavior, Hatay-Turkey

\section{Giriş}

Tarım sektöründe üretim ve verimliği artırmak, yeni teknolojileri geliştirmek, çiftçilerin gelirlerini artırmak ve bunlara bağlı olarak kırsal nüfusun refahını ve yaşam düzeylerini yükseltmek önemli ölçüde tarımsal yayım hizmetlerinin başarılı olmasına bağlıdır. Bu nedenle tarımsal yayım, 
tarımın ayakta kalması için kullanılabilecek araçların en önemlilerinden biridir. Tarımsal kalkınma, teknik bilgi ve yeniliklerin çiftçiye yönelmesi ve kabulü sürecidir. Kısacası çiftçinin değişmeye olan olumlu davranışıdır (Demirtaş ve Gürler, 1994; Kızılaslan, 1999; Özkaya ve ark., 2005; Özçatalbaş ve ark., 2010). Hükümetler, dünya genelinde geleneksel tarımsal yayım hizmetlerini sağlamak için mali sorumluluğu üstlenmişlerdir. Buradaki asıl amaç, tarımsal üretimi ya da verimliliği artırmak olmuştur (Lees, 1991). Tarımsal yayım hizmeti kırsal nüfusun bilgi, deneyim, uygulama ve tutumları üzerinde değişiklik yaratmayı amaçlayan bir eğitim faaliyetidir (Kızılaslan, 2009). Tarımsal yayımın temel amaçlarından biri de çiftçiler, toprak sahipleri ya da danışmanların da arasında bulunduğu hedef kitlede davranış değişikliği gerçekleştirmektir. Tarımsal yenilikler ancak üreticiler tarafından benimsenip uygulanmaya başlandıktan sonra yarar sağlayabilir. Yayım genellikle çiftçileri ve araştırmacıları bağlayan bir rol oynar, araştırmanın doğrudan doğasına ve konumuna, program geliştirmeye, farklı bölgelerdeki araştırma ve geliştirme önceliklerinin belirlenmesine de yardım eder (Marsh ve ark., 2000).

Kamu yayım hizmetleri, doğal kaynakların sürdürülebilir yönetimine dayalı kırsal kalkınma stratejilerinin uygulanmasında önemli bir rol oynar (Pokorny ve ark., 2005). Ulusal düzeyde tarım politikasını belirleyenlere somut öneriler götürülmesi, yayımcı, araştırmacı, çiftçi örgütleri, özel teşebbüs gibi birimlerin birlikte uyumlu olarak çalışmaları sistemin başarısını doğrudan etkileyebilmektedir (Kaimowitz, 1990).

Teknolojinin kabulünde pek çok faktör etkilidir, bunlar arasında teknolojinin özellikleri, tarım biriminin sosyo-ekonomik özellikleri, tarım işletmesine ait fiziksel özellikler, tarım birimi içinde önemli kararları alanların kişisel ve psikolojik özellikleriyle algısı ve ekonominin gelecek dönemine ilişkin beklentileri sıralanabilir. Bu faktörlerin göreceli etkisi çiftlik ve işletme türleri arasında ve zamanla farklılık gösterecektir (Garforth ve ark., 2004; Pannell ve ark., 2006). Bir tarım sisteminin ihtiyaç duyduğu teknolojik destek ve bilginin transferinde potansiyel kabul edeceklerin inançları ve tutumları dikkate alınmalıdır (Rehman ve ark., 2007). Planlı Davranış Teorisi (PDT), davranış üzerinde etkili olabilecek değişkenleri açıklamaya yönelik çalışmalarda geniş kapsamda, araştırmacılar tarafından en sık kullanılan ve ampirik olarak en çok test edilmiş bir teori olarak kabul görmektedir. Gerekçeli Davranışlar Teorisi'nin de kurucularından olan Ajzen (1991) tarafından önerilen PDT'ne göre insanların toplumsal davranışları belirli faktörlerin kontrolü altında olup belirli sebeplerden kaynaklanır ve planlanmış bir şekilde ortaya çıkar. PDT'ne göre insanların davranışlarının en yakın belirleyicisi, davranışta bulunanların niyetleridir. Davranışsal niyetler ise üç ana bileşen tarafından tahmin edilir. Bunlar sırayla; tutumlar, sübjektif (öznel) normlar ve algılanan davranışsal kontroldür. Niyet, tutum, sübjektif norm ve algılanan davranış kontrol her davranışın farklı bir yönünü ortaya koyar (Ajzen, 1991). Davranışa yönelik tutum, kişinin gerçekleşecek davranışa olan negatif veya pozitif değerlendirmesidir. Sübjektif norm, davranışı yapacak olan kişi için önemli olan kişilerin, kurum veya kuruluşların belirli bir davranışın gerçekleşmesinin ya da gerçekleşmemesinin beklentisini ifade ederken; algılanan davranış kontrol ise kişinin davranışı gösterebilmesinin ne kadar zor veya kolay 
olacağına olan inancını açıklamaktadır (Erten, 2002).

PDT Sosyal psikoloji tabanlı bir kuram olmakla birlikte farklı birçok bilim dalında yapılan çalışmada yaygın olarak kullanılmıştır. Teorinin davranışı öngörmede kullanıldığı alanların başında eğitim, sağlık, sportif etkinlikler, pazarlama ve tarım gelmektedir (Erten, 2002; Sjoberg ve ark., 2004; Tutkun ve Lehmann, 2006; Lam, 2006; Rehman ve ark., 2007; Fielding ve ark., 2008; Alam ve Sayuti, 2011; Sharifzadeh ve ark., 2012; Nocella ve ark., 2012; Ahmad ve ark., 2014; Bozkurt, 2014). PDT çerçevesinde yapılan önceki araştırmalarda tutum ve algılanan davranışsal kontrolün, davranışsal niyetle ilişkisi güçlü iken sübjektif normun ise niyetin zayıf belirleyicisi olduğu sonucuna varılmıştır (Beedell ve Rehman, 1999; Pouta ve Rekola, 2001; Ajzen, 2005).

Akdeniz bölgesindeki 1.395 bin dekarlık zeytin üretim alanında yaklaşık \%37 payla Hatay ili ilk sırada gelmektedir. Bu pay Türkiye'deki diğer iller de dikkate alındığında ise \%6 civarındadır (TÜiK, 2016). Türkiye'nin en önemli zeytin üretim alanlarının başında gelen Hatay ilinin bu yönü araştırma alanı olarak seçilmesinde etkili olmuştur. Hatay ilindeki zeytin üretimi ağırlıklı olarak yağlık çeşitlerle yapılmaktadır. Zeytinyağı üretiminde ve kalitesindeki artışlar ancak üretim miktar ve kalitesindeki artışlarla sağlanabilir. Bu noktada yayım faaliyetleriyle zeytin üretimindeki miktarın ve kalitenin artırılması için yapılacak çalışmalar oldukça önemlidir. Akdeniz bölgesinde zeytin üretiminde verim ve kalite düşüklüğü yanında bölgeye uygun çeşit seçimindeki yanlışıklar, sulama suyu kaynakları yetersizlikleri ve budama tekniği konusundaki eksiklikler olmak üzere bir takım teknik ve altyapı sorunları bulunmaktadır. Ayrıca zeytinyağı işletmelerinde temizlik ve hijyen konuları başta olmak üzere yağ kalitesini etkileyen işleme sırasındaki yanlış uygulamalar (sıcak su uygulaması, döküntü meyvelerin diğerleri ile karışık olarak işlenmesi gibi) sektörün sorunları olarak ifade edilebilir (Seçer ve Emeksiz, 2012; Doğaka, 2015).

Tarımsal yayım çalışmaları kapsamında araştırma bölgesinde zeytin yetiştiriciliği konusunda planlanan ve uygulanan çalışmalar arasında organik zeytin yetiştiriciliği, zeytinde verimin ve kalitenin artırılması, zeytin hastalık ve zararlıları ile mücadele gibi konular başta gelmektedir. Bunlara ek olarak modern meyvecilik, toprak analizi ve gübreleme, tarım sigortaları, iyi tarım uygulamaları ve çevre koruma konuları, modern sulama yöntemleri ve tarımsal desteklemeler gibi konularındaki çalışmalar sayılabilir.

Bölgede yürütülen kamu tarımsal yayım çalışmaları arasında demonstrasyonlar, tarla günleri, kurslar, çiftçi toplantıları ve gezileri, yarışmalar ve çeşitli kampanyalar sayılabilir. Bu çalışmaları desteklemek amacıyla çeşitli basılı materyal (sirküler mektup, broşür, liflet, dergi, afiş, CD ve kitap) hazırlanarak dağıtılmaktadır. Ayrıca yayım personeline yönelik olarak düzenlenen çeşitli hizmet içi eğitimlere iki yıl içinde 1200 katılım olmuştur. Hatay ilinde 2014-15 yılları içinde gerçekleştirilen kamu yayım çalışmalarına 26 bin civarında çiftçi katılmış ve bu faaliyetler sırasında 23 bin kadar çeşitli basılı materyal kullanılmıştır. Ayrıca yaklaşık 1200 yayım personeline çeşitli hizmet içi eğitimler verilmiştir. Zeytin üretiminin geliştirmesine yönelik olarak planlanan yayım ve eğitim çalışmalarına 2016 yılında da devam edilmektedir.

Planlı Davranış Teorisinin kullanımının, çiftçilerin karar alma süreçlerine yönelik yararlı bir anlayış ve davranış tahmini 
sağlayabileceği düşünülmektedir (Beedel ve Rehman, 1999). Batı Avusturalya'da yeni bir ürünün kabulüne ve yayılmasına ilişkin tarımsal yayımın etkisinin incelendiği bir çalışmada, PDT sonuçları, hem kamu tarımsal yayım faaliyetlerinin ve hem de özel danışmanları varlığının benimseme işleminin daha erken başlamasına katkıda bulunmuş olduğunu göstermektedir (Marsh ve ark., 2000). Önceki çalışmalar ışığında PDT'nin çiftçi davranışlarını tahmin için kabul edilebilir bir araç olduğu ve teorinin yayım faaliyetlerine katılma davranışını etkileyen faktörleri ortaya koymada ve anlamada etkili bir model olacağı beklenmektedir.

Bu çalışmada zeytin üreticilerinin tarımsal yayım ve eğitim faaliyetlerine katılım konusundaki davranışsal niyeti PDT çerçevesinde incelenerek, bu konuda etkili olan faktörlerin belirlenmesi ve faktörlerin (tutum, sübjektif normlar ve algılanan davranışsal kontrol faktörleri) katılım niyeti üzerine olan etkilerinin ortaya konulması amaçlanmıştır. Böylece tarımsal yayımda üreticileri teşvik edecek eğitim etkinliklerine yönelik önerilerin geliştirilebileceği ve öğretim programında bu konuda yapılabilecek düzenlemelere katkı sağlanabileceği düşünülmektedir.

\section{Materyal ve Metot}

Araştırmanın ana materyalini Hatay ili zeytin üreticilerinden anket uygulamasıyla elde edilen veriler oluşturmaktadır. Yapılan anketle zeytin üreticilerinin kamu tarımsal yayım hizmetlerinden yararlanma durumu ve yayım hizmetlerine karşı tutumları araştırılmıştır. Bu amaçla hazırlanan anket formunun ilk bölümünde işletmeci ve işletme bilgileri, tarımsal yayım ve eğitim çalışmalarına katılma durumu belirlenmiştir. İkinci bölümde ise yayım çalışmalarında PDT kapsamında davranışsal niyet, tutum, sübjektif norm ve algılanan davranışsal kontrolünü belirleyen $5^{\prime} l i$ likert tipi ölçek şeklinde 60 soru yöneltilmiştir. PDT için standart bir anket formu yoktur, bu nedenle diğer araştırmalarda kullanılmış olan anket formları örnek alınarak PDT'nin öngördüğü şekilde çalışmada kullanılacak anket formu geliştirilmiştir ve uygulanmıştır. Ankette kullanılan ölçek ve önermelerin uyum halinde olmasına dikkat edilmiştir. Burada anket yapılan bölge, tarımsal işletme ve üretim yapısı gibi çeşitli faktörler dikkate alınmıştır. Ayrıca anket sorularının hazırlanmasında PDT için anket tasarımı konulu çalışmalardan da yararlanılmıştır (Ajzen, 2006). Çalışmanın başlangıcında anket formları 15 üretici ile denenerek gerekli son düzenlemeler yapılmıştır.

\section{Örnekleme metodu}

Ana kitleyi temsil edecek örnek sayısı ortalamadan $\% 5$ hata payı ve $\% 95$ güven aralığında "Oransal Tabakalı Örnekleme" metodu formülüyle hesaplanmıştır (Yamane, 1991). Toplam zeytin üretici sayısı il Müdürlüğü Çiftçi Kayıt Sisteminden yararlanılarak belirlenmiştir. Örneklemeyle Hatay ilindeki zeytin üreticilerini temsil etmek üzere 3 ilçeden (Altınözü, Kırıkhan ve Yayladağı) toplam 175 üretici belirlenmiştir. Araştırma verileri 2015 yılı üretim dönemi sonunda (Kasım-Aralık) elde edilmiştir (Çizelge 1). 
Çizelge 1. Hatay İlinde İlçelere Göre Zeytin Üretici Sayısı, Üretim Alanı (da) ve Örnek Sayısı Table 1. Olive Producers Number According to the Towns, Production Land (da) and Sample Size in Hatay Province

\begin{tabular}{|l|c|c|c|c|}
\hline $\begin{array}{l}\text { Illçeler } \\
\text { Towns }\end{array}$ & $\begin{array}{c}\text { Üretici sayısı } \\
\text { Farmer number }\end{array}$ & $\begin{array}{c}\text { Oran (\%) } \\
(\%) \text { Rate }\end{array}$ & $\begin{array}{c}\text { Zeytin alanı } \\
\text { Olive land }\end{array}$ & $\begin{array}{c}\text { Örnek sayısı } \\
\text { Sample size }\end{array}$ \\
\hline Altınözü & 1396 & 39.41 & 18443.61 & 105 \\
\hline Antakya & 199 & 5.62 & 1927.50 & - \\
\hline Arsuz & 157 & 4.43 & 1957.24 & - \\
\hline İskenderun & 142 & 4.01 & 1691.53 & - \\
\hline Kırıkhan & 215 & 6.07 & 7775.03 & 54 \\
\hline Yayladağı & 728 & 20.55 & 7819.33 & - \\
\hline Diğerleri (Others) & 705 & 19.90 & 7004.92 & 175 \\
\hline Toplam (Total) & 3542 & 100.00 & 46619.16 & \\
\hline
\end{tabular}

Kaynak: GTHB Hatay III Müdürlüğü ÇKS Veri tabanı (2015)

Diğer ilçeler: Belen, Defne, Dörtyol, Erzin, Hassa, Kumlu, Reyhanlı, Samandağ

\section{Araştırma modeli}

Çalışmada zeytin üreticilerinin bölgelerinde düzenlenen ve kendilerine yönelik kamu tarımsal yayım çalışmalarına katılma davranışları ve davranışsal niyetleri ölçülmüştür. Kamu yayım faaliyetlerine katılma niyeti üzerine etkili olan PDT unsurlarından tutumlar, sübjektif normlar ve algılanan davranışsal kontrol unsurları bağımsız değişkenler olarak ele alınmış, bu değişkenlerin tarımsal yayıma katılma davranışı ve niyetini tahmin etmede yeterli olacakları kabul edilmiştir (Şekil 1). Teoriye göre, bir davranışın gerçekleşebilmesi için öncelikle o davranışa yönelik niyetin oluşması gerekmektedir. Davranışa yönelik niyet ne kadar güçlü ise davranışın ortaya çıkma olasılığı da o kadar fazladır. Teorinin ikinci kısmı inanç boyutlarından (davranış inançları, normatif inançlar, kontrol inançları) oluşmaktadır. Tutum, sübjektif norm ve algılanan davranış kontrolünün bilişsel ve duyuşsal temelleri olan inançlar, PDT'de merkezi bir rol oynamaktadır. Duygu, kişilik özellikleri, zekâ, değer, yaş, cinsiyet, eğitim, bilgi, deneyim, ırk, gelir düzeyi gibi değişkenler inançların oluşumunda belirleyici olmaktadır (Ajzen, 2005).

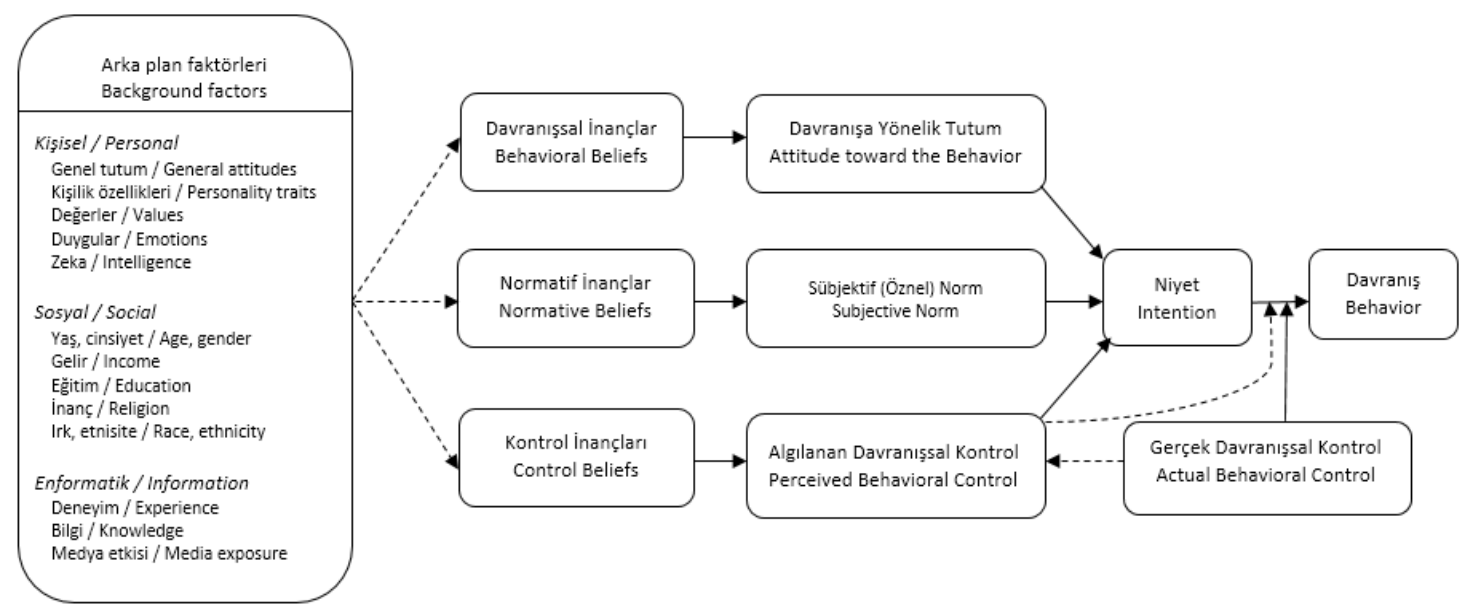

Şekil 1. PDT Modeli Faktörleri (Ajzen ve Fishben, 2005)

Figure 1. ToPB Model Factors (Ajzen and Fishben, 2005) 
Ancak, aynı teoriye göre, algılanan davranışsal kontrol, bazen niyetin aracılı̆̆ı olmadan davranışı doğrudan açıklayabilmektedir. Bir kişinin davranışı "Davranışa Yönelik Niyet/Amac"ın kuvvetine bağlıdır. Davranışa yönelik niyet ne kadar güçlü ise gerçek davranışın gösterilme olasılı̆̆ı da o kadar yüksektir. Bu durumda "Davranışa Yönelik Niyet" kişinin davranışı gösterebilmek için harcadığı çabaların derecesini gösteren bir faktördür. Genel bir kural olarak "Davranışa Yönelik Tutum" ne kadar olumlu ise, "Sübjektif Norm" ne kadar kabul edilebilir ise ve "Algılanan Davranışsal Kontrol" ne kadar güçlü olursa veya davranışlar üzerindeki kontrol ne kadar yeterli ise o davranışı yerine getirme Amacı/Niyeti de o kadar kuvvetli olacaktır.
PDT kapsamınsa bugüne kadar yapılan çalışmalarda genellikle araştırmaya katılan bireyin gerçekleştirdiğini ifade ettiği davranışlar üzerinden yapılmıştır. Çünkü bireylerin davranışlarını uzaktan gözlemleyerek yapılabilecek çalışmalar oldukça sınırıdır. Araştırma kaynakları çoğu zaman davranışları gözlemleyerek belirlemeye izin vermez. Bu nedenle PDT kullanılan araştırma çalışmalarında "Davranış" yerine "Davranışa Yönelik Niyet"in ölçülmesi yoluna gidilmektedir (Davranış $(B) \cong$ Davranışsal Niyet $(B I)$ ). Davranış ve Davranışsal Niyete ait regresyon denklemleri aşağıdaki Eşitlik 1'deki gibidir (Ajzen, 1991);

Davranış $(B)=\beta_{0}+\beta_{1} B I+\beta_{2} P B C$

Davranışsal Niyet $(B I)=\alpha_{0}+\alpha_{1} A+\alpha_{2} S N+\alpha_{3} P B C$

PDT modelinde belirtildiği gibi "Tutumlar (A)" her davranışın inanç gücü çarpılarak hesaplanır. Burada davranışsal inançlar $\left(b_{i}\right)$, inancın niteliğinin değerlendirilmesiyle $\left(e_{i}\right)$ çarpılır (Eşitlik 2).

$$
A=\sum_{i=1}^{I} b_{i} e_{i}
$$

Sübjektif Normlar (SN) belirlenirken, her bir normatif inanç $\left(n_{j}\right)$, söz konusu motivasyon kaynağı $\left(m_{j}\right)$ ile çarpılarak elde edilir (Eşitlik 3).

$$
S N=\sum_{j=1}^{J} n_{j} m_{j}
$$

Algılanan Davranışsal Kontrol (PBC), kontrol inançları $\left(c_{k}\right)$ ile bu kontrol faktörlerinden algılanan gücün $\left(p_{k}\right)$ çarpımları sonucunda elde edilmektedir (Eşitlik 4).
$P B C=\sum_{k=1}^{K} c_{k} p_{k}$

Araştırmada toplanan veriler istatistik analizler öncesinde normallik, güvenilirlik ve yeterlilik bakımından değerlendirilmiş ve bir sorun olmadığı belirlenmiştir. PDT modeline göre veriler Korelasyon ve Regresyon Analizi yapılarak değerlendirilmiştir. Üreticilerin kişisel özelikleri ile yayım faaliyetlerine katılma niyetleri arasındaki ilişkiler Varyans analizi ile değerlendirilmiştir. Verilerin analizinde IBM SPSS 22 istatistik paket programı kullanılmıştır.

\section{Bulgular ve Tartışma}

\section{Zeytin Üreticileri Demografik Özellikleri}

Hatay ilindeki zeytin üreticileri, zeytin bahçesi alanları dikkate alınarak ve istatistiki 
olarak ana kitleyi temsil edecek şekilde tesadüflüğe de dikkat edilerek belirlenmiştir. İşletmelerin \%61'i küçük, (10 dekar ve daha az bahçe alanı), \%21 orta (11-20 dekar arası bahçe alanı) ve \%18'ide büyük (21 dekar ve daha büyük bahçe alanı) işletmelerden oluşmaktadır. Yani işletmelerin çoğunluğunun küçük ve orta büyüklükteki (\%82) zeytin bahçesine sahip olduğu söylenebilir. İşletmelerin \%65' i karma üretim (bitkisel ve hayvansal üretim) yapan işletme tipindedir. İşletmelerdeki zeytin alanı genişliği 5-131 dekar arasında değişkenlik göstermekte olup ortalaması 18.49 dekardır. İşletme sahiplerinin \%92'si (161 kişi) erkeklerden oluşmuştur. $\mathrm{Bu}$ işletmecilerin yaşları 20-69 arasında değişmekte olup ortalama yaş ise $44^{\prime}$ tür. Tarımsal deneyim süreleri 7-55 yıl arasında değişmekte olup ortalaması 30 yıla yakındır (29.49 yıl).
İşletmecilerin eğitim seviyeleri oldukça düşüktür (ilköğretim \%41; yükseköğrenim \%11), tarımsal bilgi kaynakları daha çok işletme çevresinde bulunan ve bunlara girdi sağlayan işletmeciler ve iletişim içinde olunan komşu ve akrabalardan (\%62) oluşmaktadır. Serada tarımsal üretimde çiftçilerin girdiler konusunda \%90 üzerinde bayileri bilgi kaynağı olarak gördüğü, kamu yayım elemanlarının ise çok az dikkate alındığı belirlenmiştir (Yalçın ve Boz, 2007). Kırsal alanda üreticilerin birbirleriyle yakın temas içinde olması ve aile bağlarının kuvvetli olmasına bağı olarak tarımsal bilgi akışının daha çok aile bireyleri ve komşu üreticiler arasında yoğunlaştığı bilinmektedir. Çizelge 2'de görüldüğü gibi örneğe alınan işletmeler sosyo-demografik özellikler bakımından bölgenin geniş bir yelpazesini temsil etmektedir.

Çizelge 2. Zeytin Üreticilerin Bazı Sosyo-Demografik Özellikleri (\% oran; $n=175$ )

Table 2. Some Socio-Demographic Characteristics of Olive Producers (rate \%; $n=175$ )

\begin{tabular}{|c|c|c|c|c|c|}
\hline \multirow{2}{*}{$\begin{array}{l}\text { Cinsiyet } \\
\text { Sex }\end{array}$} & Erkek (Male) & 92.00 & \multirow{6}{*}{$\begin{array}{l}\text { Deneyim (yıl) } \\
\text { Experience (year) }\end{array}$} & $\leq-10$ & 7.43 \\
\hline & Kadın (Female) & 8.00 & & 11-19 & 17.14 \\
\hline \multirow{6}{*}{$\begin{array}{l}\text { Yaş } \\
\text { Age }\end{array}$} & $\leq-25$ & 4.57 & & $20-29$ & 21.14 \\
\hline & $26-35$ & 24.00 & & $30-39$ & 25.71 \\
\hline & $36-45$ & 24.57 & & $40-\leq$ & 28.57 \\
\hline & $46-55$ & 25.14 & & Ortalama (Average) & 29.49 \\
\hline & $56-\leq$ & 21.71 & \multirow{4}{*}{$\begin{array}{l}\text { Bilgi kaynağı } \\
\text { information } \\
\text { source }\end{array}$} & $\begin{array}{l}\text { Bayi/Tüccar } \\
\text { (Reseller/Dealer) }\end{array}$ & 32.44 \\
\hline & Ortalama (Average) & 44.24 & & $\begin{array}{l}\text { Komşu/Akraba } \\
\text { (Neighbor / Relative) }\end{array}$ & 29.75 \\
\hline \multirow{6}{*}{$\begin{array}{l}\text { Eğitim } \\
\text { Education }\end{array}$} & $\begin{array}{l}\text { Okur-yazar değil } \\
\text { (Illiterate) }\end{array}$ & 3.43 & & $\begin{array}{l}\text { Yayımcı/Danışman } \\
\text { (Extension } \\
\text { Consultant) }\end{array}$ & 26.30 \\
\hline & Okur-yazar (Literate) & 22.29 & & Medya (Media) & 11.52 \\
\hline & İlköğretim (primary) & 40.57 & \multirow{2}{*}{$\begin{array}{l}\text { İşletme türü } \\
\text { Farm type }\end{array}$} & Bitkisel (Crops) & 34.86 \\
\hline & Lise (High school) & 22.86 & & Karma (Mixed) & 65.14 \\
\hline & Ön lisans (vocational) & 8.00 & \multirow{3}{*}{$\begin{array}{l}\text { Zeytin alanı (da) } \\
\text { Olive land (da) }\end{array}$} & $\leq-10$ & 61.14 \\
\hline & $\begin{array}{l}\text { Lisans } \\
\text { (Undergraduate) }\end{array}$ & 2.86 & & $11-20$ & 21.14 \\
\hline \multirow{4}{*}{$\begin{array}{l}\text { Gelir (yıllık/も) } \\
\text { Income } \\
\text { (annual/も) }\end{array}$} & $\leq-15999$ & 27.43 & & $21-\leq$ & 17.71 \\
\hline & $16000-24999$ & 33.14 & \multirow{3}{*}{$\begin{array}{l}\text { Bölge } \\
\text { Region }\end{array}$} & Altınözü & 60.00 \\
\hline & $25000-49999$ & 31.43 & & Yayladağı & 30.86 \\
\hline & $50000-\leq$ & 8.00 & & Kırıkhan & 9.14 \\
\hline
\end{tabular}


Üreticilerin tarımsal yayım çalışmalarına katılma davranışı konusunda, geçmişteki ve yakın gelecekte planlanan davranışları Çizelge 3'te verilmiştir. Üreticilerin \%55'i geçmişte herhangi bir tarımsal yayım faaliyetine katılmamıştır. Yine üreticilerin \%43'ü gelecek yıl herhangi bir tarımsal yayım programına katılma niyeti belirtmemiştir. Buna göre zeytin üreticilerinin yaklaşık yarısının herhangi bir kamu tarımsal yayım çalışmasına katılmadığı görülmektedir.
Üreticilerin \%34'ü ise geçmişte düzenlenmiş ve gelecekte düzenlenecek olan kamu yayım çalışmalarından ancak birine katılmış veya katılmayı düşünmektedir. Birden fazla faaliyete katılma davranışı veya katılma niyeti oldukça düşük seviyelerdedir. Bu noktada üreticilerin yayım çalışmalarına katılma niyetini etkileyen faktörlerin belirlenmesi ve buna göre katılımı artırıcı önlemlere ihtiyaç olduğu görülmektedir.

Çizelge 3. Üreticilerin Tarımsal Yayım ve Eğitim Çalışmalarına Katılımı

Table 3. Participation of Farmers in Agricultural Extension and Training Activities

\begin{tabular}{|c|r|r|r|r|r|}
\hline \multicolumn{2}{|l}{$\begin{array}{l}\text { Son } 5 \text { yıl içindeki katılım sayısı } \\
\text { (Number of participation in the last } 5 \text { years) }\end{array}$} & \multicolumn{3}{|l|}{$\begin{array}{l}\text { Gelecek yıl planlanan katılım sayısı } \\
\text { (Number of planned participation for next year) }\end{array}$} \\
\hline $\begin{array}{c}\text { Katılım sayısı } \\
\text { (Participation number) }\end{array}$ & \multicolumn{1}{c|}{$\mathrm{n}$} & $\%$ & $\begin{array}{c}\text { Katılım sayısı } \\
\text { (Participation number) }\end{array}$ & $\mathrm{n}$ & $\%$ \\
\hline 0 & 97 & 55.43 & 0 & 75 & 42.86 \\
\hline 1 & 60 & 34.29 & 1 & 59 & 33.71 \\
\hline 2 & 16 & 9.14 & 2 & 27 & 15.43 \\
\hline 3 & 2 & 1.14 & 3 & 9 & 5.14 \\
\hline 4 & 0 & 0.00 & 4 & 5 & 2.86 \\
\hline Toplam (Total) & 175 & 100.00 & Toplam (Total) & 175 & 100.00 \\
\hline
\end{tabular}

Ekolojik tarımsal üretim konusunda yapılan bir çalışmada çiftçilerin düzenlenen toplantı ve konferanslara $\% 74$, broşürlere $\% 26$ ve gezilere $\% 11$ oranında ilgi göstermiş olduğu belirlenmiştir (Boyacı ve Karaturhan, 2003). Üreticilerin yayım çalışmalarına katılımına, yapılan faaliyetin türü, algılanan faydası, zamanı ve yeri etkili olmaktadır. Faaliyetlerin planlanmasında yer, zaman ve faaliyet türü bakımından uygunluk çok iyi ayarlanmalıdır. Algılanan faydanın daha yüksek seviyede oluşması için üreticilere ayrıntılı tanıtımlarla açıklama yapılmasında fayda vardır.

Çizelge 4. PDT Model Yapıları Arasındaki Ortalama, Standart Sapma ve Korelasyon Değerleri Table 4. TOPB Model Structure Average Values, Standard Deviation and Correlation Values

\begin{tabular}{|l|c|c|c|c|c|c|}
\hline Değişkenler (Variables) & Ort. (Average) & SD & 1 & 2 & 3 & 4 \\
\hline 1. Davranışsal Niyet (Behavioral Intention) & 3.38 & 0.88 & 1.000 & & & \\
\hline 2. Davranışa Yönelik Tutum (Attitute) & 3.39 & 0.53 & 0.659 & 1.000 & & \\
\hline 3. Sübjektif Normlar (Subjective Norms) & 3.28 & 0.69 & 0.582 & 0.571 & 1.000 & \\
\hline $\begin{array}{l}\text { 4. Algılanan Davranışsal Kontrol } \\
\text { (Percieved Behavioral Control) }\end{array}$ & 3.08 & 0.31 & 0.476 & 0.384 & 0.661 & 1.000 \\
\hline
\end{tabular}

Tüm korelasyonlar 0.01 düzeyinde anlamlıdır.

Tarımsal yayım faaliyetlerine katılma davranışını ölçmek amacıyla kullanılan PDT modelinde yer alan yapılar arasındaki korelasyon, ortalama ve standart sapma değerleri aşağıda görülmektedir (Çizelge 4). Modeldeki tüm değişkenler arasındaki korelasyon değerleri istatistiki olarak önemli bulunmuştur $(p<0.01)$. Üreticilerin tarımsal 
yayım faaliyetlerine katılma niyeti ile PDT modelindeki yapılar arasında pozitif yönlü ve anlamlı bir ilişki bulunmaktadır. Değişkenlere ait beşli ölçek değerlerinin tamamı ortalama (nötr) değerin üzerinde yer almıştır. Model değişkenlerine ait bu birincil istatistik değerleri üreticilerin davranışsal niyetini ölçme konusunda olumlu bir gösterge olarak kabul edilebilir.

PDT kapsamında üreticilerin yayım çalışmalarına katılımdaki davranışsal niyeti üzerine etkili olan değişkenlerin doğrusal regresyon sonuçları Çizelge 5'te gösterilmiştir. Bağımsız değişkenlerin davranışsal niyetin önemli bir kısmındaki varyansı açıkladığı (\%51) ve katsayı tahminlerinin istatistiksel olarak anlamlı olduğu görülmüştür. Başka bir deyişle tarımsal yayım faaliyetlerine katılma niyetinin \%51'i bu faktörlere bağlı olarak şekillenmektedir. Yapılan regresyon analizi sonuçlarına göre üreticilerin yayım faaliyetlerine katılma niyeti üzerinde en etkili değişken tutum $\left(\alpha_{1}=0.484 ; p<0.003\right)$, ikinci etkili değişken $S N$ ve en az etkisi olan değişken ise PBC $\quad\left(\alpha_{3}=0.157 ; \quad p<0.012\right)$ olmuştur. $\mathrm{Bu}$ sonuçlara göre zeytin üreticilerinin gelecekteki yayım programlarına katılımını artırmak için yapılacak çalışmalar öncelikle üreticinin tutumunu değiştirmeye yönelik olmalıdır. Üreticilerin yayım çalışmalarına katılmadaki tutumunu ölçen davranışsal inanç soruları incelendiğinde en yüksek ortalama puan "Faydalıdır" yargısından elde edilmiş ve inancın niteliğinin değerlendirildiği sorulardan ise "Uygunluk" en yüksek ortalama puanı vermiştir. Yani üreticiler faydalı ve uygunluk bakımından olumlu bulduğu yayım çalışmalarına katılmada en yüksek tutumu göstermektedir.

Belçika'da üç farklı toprak koruma uygulamalarının benimsenmesinin incelendiği bir çalışmada PDT'inde en iyi açıklayıcı faktör, tutum olarak belirlenmiştir. Davranışsal niyet için açıklanan varyans miktarı modellere göre \%44-70 arasında değişiklik göstermiştir. Davranışsal niyetin tahmininde tutum, yüksek bir açıklayıcı varyans üretmesine rağmen sübjektif norm, algılanan zorluk ve algılanan kontrol anlamlı olmayan katsayılar üretmiştir (Wauters ve ark. 2010). Çiftçilerin tarımsal iklim bilgisini kullanımı üzerine yapılan bir araştırmada ise tutum ile davranışsal niyeti arasında güçlü bir ilişkilinin var olduğu belirlenmiştir (Sharifzadeh, 2012). Tarımsal sulamadaki koruma teknolojilerinin benimsenme kararlarında, algılanan davranış kontrolünün etkisinin incelendiği bir çalışmada, algılanan davranışsal kontrol için çiftçilerin yatırım kararlarında tam iradesinin olmadığı görülmüştür. Ancak, algılanan kontrol anlamlı olduğunda, PDT'nin bazı değişkenleri davranışı daha doğru açıklamıştır. Sübjektif norm bakımından su tasarrufunda (mikro sulama teknolojileri ile) çiftçiler toplumdan daha fazla etkilenerek yenilikleri kabul davranışını göstermiştir (Lynne ve ark. 1995). Çiftçi tutumlarını anlamada elde edilen bulgular, teknolojiye karşı tutumlarında çiftçilerin niyetinin onu kabul edip etmemeye güçlü bir etkiye sahip olduğunu teyit etmiştir. Dikkatlice planlanmış iletişim, benimsenmeyi destekleyen tutumları güçlendirmekte ve davranışa karşı engelleri olanlara yardımcı olabilmektedir (Garforth, ve ark. 2004). Sürdürülebilir tarım uygulamalarının benimsenmesinde tutumlar ve algılanan davranışsal kontrol, çalışmalar sırasında niyetlerin önemli belirleyicileri olarak ortaya çıkmıştır. Geçmişteki davranış, tutum ve algılanan davranışsal kontrol, niyetlerin önemli belirleyicileri olarak bulunurken, niyetler önemli ölçüde üreticilerin bildirdiği davranışları tahmin etmiştir (Fielding ve ark. 
2008). Armitage ve Conner (2001) tarafından 185 çalışanın bir meta analizinde niyet ve algılanan davranışsal kontrol, davranış varyansının ortalama \%27'sini açıklamıştır ve yine bu çalışmada tutum, sübjektif norm ve algılanan davranışsal kontrol, niyetlerin varyansının ortalama \%39'unu açıklamıştır.

Tutumlar ve algılanan davranışsal kontroller önceki çalışmalarda niyetlerin önemli belirleyicileri olarak ortaya çıkmıştır. Zeytin üreticilerinin yayım çalışmalarına katılmadaki davranışsal niyeti üzerinde de bu değişkenlerin önemli belirleyiciler olduğu ortaya çıkmış ve bu sonuç önceki çalışmalarla örtüşmektedir. Aynı şekilde sübjektif normların zayıf olan bulguları da önceki araştırma sonuçları ile tutarlıdır.

Çizelge 5. Üreticilerin Yayım Çalışmalarına Katıım Niyeti Regresyon Sonuçları Table 5. Farmers Intention to Participate in Extension Work of Regression Results

\begin{tabular}{|c|c|c|c|c|c|}
\hline \multirow{4}{*}{ 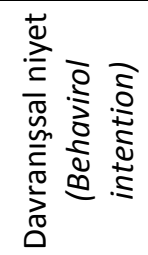 } & $\begin{array}{l}\text { Bağımsız değişkenler } \\
\text { (Independent variables) }\end{array}$ & $r$ & $\alpha_{i}$ & p-değeri & $\mathrm{R}^{2}$ \\
\hline & Tutum (Attitude) & 0.659 & 0.484 & 0.003 & \multirow{3}{*}{0.51} \\
\hline & Öznel Normlar (Subjective norms) & 0.582 & 0.202 & 0.000 & \\
\hline & $\begin{array}{l}\text { Algılanan Davranışsal Kontrol } \\
\text { (Percieved Behavioral Control) }\end{array}$ & 0.476 & 0.157 & 0.012 & \\
\hline
\end{tabular}

Şekil 2'de üreticilerin bazı özelliklerinin tarımsal yayım çalışmalarına katılma niyeti üzerindeki etkileri gösterilmiştir. Üretici özelliklerinden yaş, tarımsal yayım çalışmaları hakkındaki bilgi seviyesi, tarımsal deneyim ve eğitim seviyesi ile zeytin bahçesi genişliği arasındaki farklar önemli bulunmuştur $(p<0.001)$. Zeytin üretim bölgeleri, üreticilerin yıllık gelirleri ve cinsiyetleri arasında ise anlamlı bir farklılık bulunamamıştır. Bu sonuçlara göre kamu tarımsal yayım hizmetlerinin özellikle küçük ölçekli işletmelere sahip, deneyimi az ve yayım bilgisi çok olan genç üreticiler bakımından önemli olduğu anlaşılmaktadır.

Organik avokado üretiminin benimsenmesinde PDT ile yapılan analiz sonuçlarına göre yaş ve eğitim, organik üretime başlama niyeti üzerinde etkilidir. Sonuçlara göre yaş, genellikle benimseme kararları üzerinde olumsuz bir etkiye sahip iken eğitimin etkisi ise olumludur. Bu sonuçlara göre avokado üreticilerine organik üretimle ilgili herhangi bir destek verilmesi söz konusu olduğunda bu girişim en çok genç ve daha eğitimli çiftçiler arasında etkili olacağı tespit edilmiştir (Hattam, 2006). Önceki çalışmalarda çevresel davranış üzerindeki demografik değişkenlerin etkisi ise karışık sonuçlar göstermiştir. Sürdürülebilir tarım uygulamalarına giriş kararlarında demografik değişkenlerin etkileri ön analizlerle incelenmiş ve bunlardan hiç birinin davranışsal niyeti tahmininde önemli olmadığı görülerek analizlerden çıkarılmıştır (Fielding ve ark. 2008). Bir başka çalışmada cinsiyet ve çevre davranışı arasında anlamlı bir ilişki bulunamazken bazı çalışmalarda kadınların çevreci davranışa daha eğilimli olduğu bulunmuştur (Tarrant ve Cordell, 1997). Benzer şekilde Karami ve Mansoorabadi (2008), tarafından yapılan bir çalışmada kadın çiftçilerin sürdürülebilir tarım davranışına yönelik daha olumlu tutum içerisinde olduğu belirlenmiştir. Zeytin üreticileri arasında ise erkek ve kadın üreticilerin yayım faaliyetine katılma niyetleri birbirine yakın olmakla birlikte kadın üreticiler biraz daha ön plana çıkmıştır. 
Tarımsal yayım servisinden çiftçi memnuniyetini etkileyen faktörlerin incelendiği bir araştırmada, algılanan ekonomik getiri, yayımcı elemanlarla düzenli temas, aile büyüklüğü ve tarım dışı gelir olumlu ilişki göstermiştir, buna karşın sınırlı teknoloji seçimi, yüksek girdi fiyatları, uygunsuz kredi sistemi ile yayımcı ve yerel politikacılar arasındaki sınırlar memnuniyetsizlik faktörleri olarak belirtilmiştir (Elias ve ark., 2015). Hassas tarım teknolojileri kullanmaya yönelik bir çalışmada güven tutumları, net fayda algısı, çiftlik büyüklüğü ve çiftçi eğitim düzeyi, hassas tarım teknolojilerini benimseme niyetini olumlu etkilemiştir (Adrian ve ark., 2005). Bir başka çalışmada üreticilerin yaşları ile yayım çalışmalarına katılma niyeti arasındaki ilişki genç üreticilerin lehinedir ve üretici yaşı arttıkça bu niyet önemli miktarda azalma göstermektedir. Üreticilerin gelir ve işlediği arazi miktarı arttıkça yeni tarım bilgi ve tekniklerinden haberdar olma ile bunları uygulama düzeyi artış göstermiştir (Kızılaslan ve Ünal, 2013).

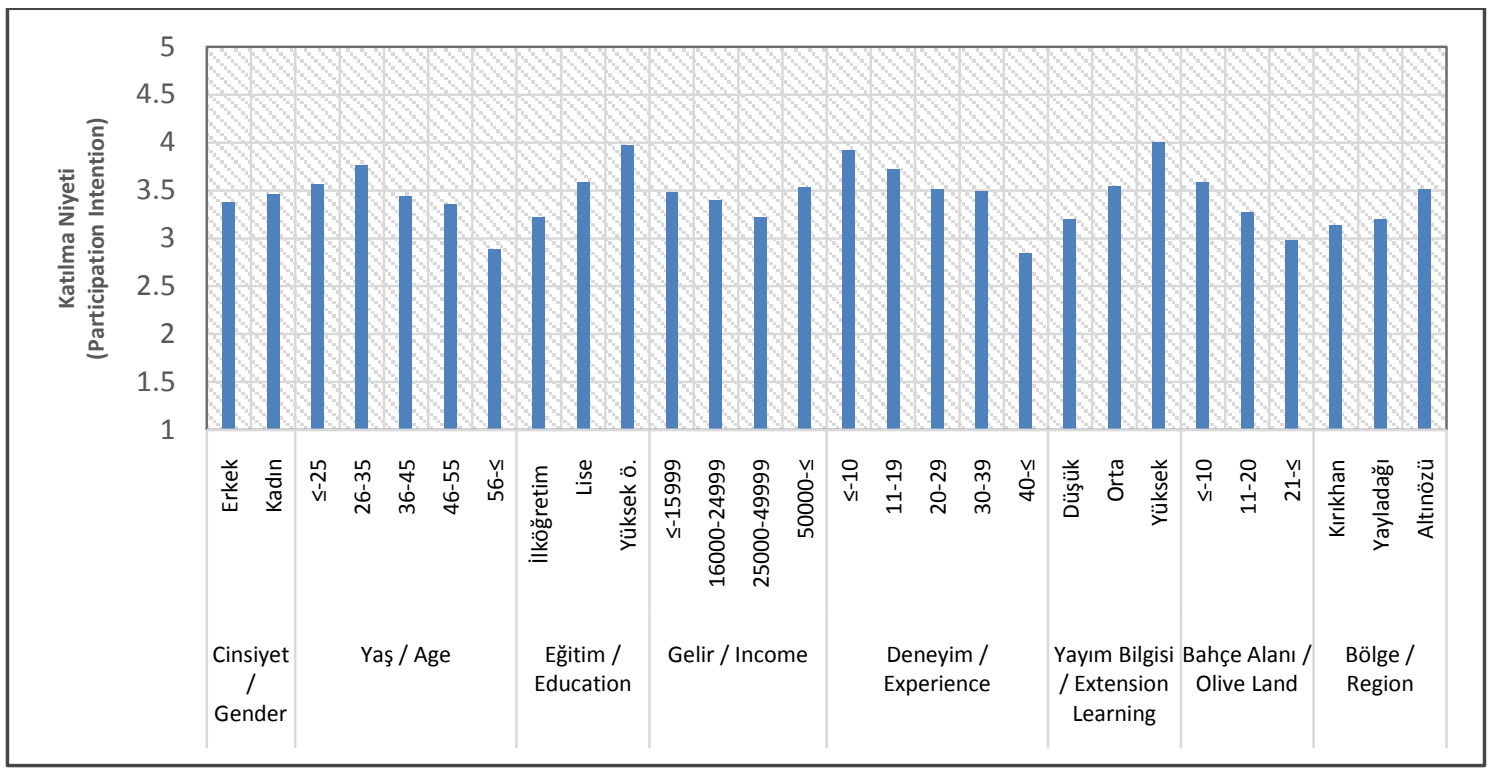

Şekil 2. Üreticilerin Kişisel Özelliklerin Tarımsal Yayım Faaliyetlerine Katılma Niyeti Üzerine Etkisi

Figure 2. Impact of the Producers' Personal Characteristics on the Intention to Participate in Agricultural Extension Activities

\section{Sonuçlar}

Çalışmada incelenen zeytin üreticileri arasında kamu tarımsal yayım çalışmalarına katılma davranışının ve gelecekte de katılma niyetinin oldukça düşük seviyelerde olduğu belirlenmiştir. Buna karşın ilgili yayım kuruluşu tarafından bölgede zeytin üreticilerine yönelik olarak yetiştiricilik ve işletmecilik sorunlarının çözümüne yönelik yayım ve eğitim çalışmaları yeterince düzenlenmektedir. Bu çalışmada üreticilerin tarımsal yayım çalışmalarına katılma davranışında etkili olan faktörlerin belirlenmesi amacıyla PDT kullanılarak davranışsal niyetleri ölçülmüştür. PDT bu çalışmanın teorik çerçevesi ile birlikte davranışsal niyetin belirlenmesinde de olumlu sonuçlar üretmiş̧ir. Modelde ele alınan değişkenler arasındaki analiz 
sonuçları, davranışsal niyetin en önemli belirleyicisinin davranışa yönelik tutum olduğunu göstermiştir. Zeytin üreticilerinin tarımsal yayım çalışmalarına katııımını artırmak için öncelikle tutumlarında değişiklik yapılması için çalışılması gerektiği belirlenmiştir. Üreticilerin tutumunu belirlemede öne çıkan yargılara göre de yayım çalışmasının faydalı ve uygun olması daha önemli olarak değerlendirilmiştir. Zeytin üreticilerinin ve işletmelerinin bazı özellikleriyle yayım çalışmalarına katılma niyeti arasındaki ilişki incelendiğinde küçük ölçekli işletmeler içinde tarımsal deneyimi az ve yayım bilgisi çok olan işletmeciler öne çıkmıştır.

Arazi büyüklüğü, verimlilik veya üretim yapısı gibi farklı özelliklere sahip üreticilerin, farklı hedef ve ihtiyaçları vardır, bu yüzden, bu tür yayım programlarındaki üreticilerin farklı ihtiyaçlarının belirlenmesi çalışmalardaki etkinliğini artıracaktır. Tarımsal yayım çalışmalarına katılma konusunda direnç gösteren çiftçileri ikna etmek için çok iyi tanıtım ve gösteriler düzenlenmelidir. Üniversiteler yayım alanında daha aktif bir eğitim rolü üstlenebilir. Tutumlar çiftlik ve çiftçi türleri arasında değişmektedir. Bu nedenle bilgi transferi için kullanılan araçlar teknolojiye özel ve hedef kitleye uygun olmalıdır. Yerel ve kişisel temaslar genellikle daha uzak ve kurumsal kaynaklara göre çiftçilerin niyetleri hakkında daha fazla etkiye sahiptir. Eğitim kişilerin kaynaklara ve hedeflere ulaşmada kapasitesini artırır, daha iyi eğitim durumu daha akıllıca yayım hizmetlerinden yararlanmayı sağlar. Tarımsal yayım hizmetlerinin düzenli olması ve sıklığı ile farklı iletişim araçlarının kullanılması etkinlik artışı sağlayacaktır. Yayım hizmetlerinin üretici ihtiyaçlarına uygun ve talep odaklı olması katılım ve hizmetlerden yararlanmayı artıracağı düşünülmektedir. Kamu yayım hizmetleri kırsal kalkınma programlarının uygulanmasında önemli rol oynar. Ancak kamu bu konuda sınırlı mali ve insan kaynağına sahiptir. Yayım hizmetlerinin tamamen özelleştirilmesi ise örgütsel düzeyde yapısal yönetim ihtiyacı ortaya çıkaracaktır. Bu noktada kamu ve özel yayım hizmetleri arasında bir denge oluşturularak etkinlik artışı sağlanabilir. Yayım faaliyetlerinin etkinliğinin ve benimsenmesinin üretimde verimlilik, kalite ve modern üretim teknikleri kullanımı bakımından sağlanan gelişmelere etkisinin araştırılması yararlı sonuçlar ortaya koyacaktır.

\section{Kaynaklar}

Adrian, A.M., Norwood, S.H., Mask, P.L. 2005. Producers' perceptions and attitudes toward precision agriculture technologies. Computers and Electronics in Agriculture, 48: 256-271.

Ahmad, M.H, Shahar S, Mohd N.I, Teng F, Manaf ZA, Sakian NIM, Omar B. 2014. Applying theory of planned behavior to predict exercise maintenance in sarcopenic elderly. Clinical Interventions in Aging, 9: 1551-1561.

Ajzen, I. 1991. The theory of planned behavior. Organizational Behaviour and Human Decision Processes, 50: 179-211.

Ajzen, I. 2005. Attitudes, Personality and Behavior (2nd. Edition), McGraw - Hill, Milton-Keynes, England: Open University Press.

Ajzen, I. 2006. Constructing a TpB Questionnaire: Conceptual and methodological considerations http://www.unibielefeld.de/ikg/zick/ajzenconstructionatp bquestionnaire.pdf Erişim tarihi: 04.06.2016.

Ajzen, I., Fishbein, M. 2005. The Influence of Attitudes on Behavior. In book: The Handbook of Attitudes, Publisher: Mahwah, N.J: Lawrence Erlbaum Associates, Editors: D. Albarracín, B.T. Johnson, M.P. Zanna, pp.173-221. http://web.psych.utoronto.ca/psy320/Req 
uiredreadings_files/4-1.pdf Erişim tarihi: 10.06.2016.

Alam, S.S, Sayuti, N.M. 2011. Applying the theory of planned behavior (TPB) in halal food purchasing. International Journal of Commerce and Management, 21(1): 8-20.

Armitage, C.J., Conner, M. 2001. Efficacy of the theory of planned behavior: A metaanalytic review. British Journal of Social Psychology, 40: 471-499.

Beedel, J.D.C., Rehman, T. 1999. Explaining farmers' conservation behavior: Why do farmers behave the way they do? Journal of Environmental Management, 57: 165176.

Boyacı, M., Karaturhan, B. 2003. Ekolojik üretimde tarımsal yayım faaliyetleri üzerine bir araştırma. Ege Üniversitesi Ziraat Fakültesi Dergisi, 40(3): 113-120.

Bozkurt, Ö.Ç. 2014. Planlanmış davranış teorisi çerçevesinde öğrencilerin girişimci olma niyetlerinin incelenmesi. Ekonomi ve Yönetim Araştırmaları Dergisi, 3(1): 27-46.

Demirtaş, M., Gürler, A.Z. 1994. Türkiye'de uygulamaya konulan I. Tarımsal Yayım ve Uygulamalı Araştırma Projesinin Türk Tarımının Gelişmesine Etkileri. Türkiye I. Tarım Ekonomisi Kongresi, İzmir, Cilt:2, s.402-411.

Doğaka, 2015. TR63 Bölgesi Zeytincilik Sektör Raporu 2015. Doğu Akdeniz Kalkınma Ajansı, Hatay. http://www.dogaka.gov.tr/Icerik/Dosya/w ww.dogaka.gov.tr_619_LZOP55ES_Zeytinci lik-Sektor-Raporu-2015.pdf Erişim tarihi: 15.06.2016.

Elias, A., Nohmi, M., Yasunobu, K., Ishida, A. 2015. Farmers' satisfaction with agricultural extension service and its influencing factors: A case study in North West Ethiopia. Journal Agricultural Science and Technology, 17: 39-53.

Erten, S. 2002. Planlanmış davranış teorisi ile uygulamalı ders iş̧leme öğretim metodu. Hacettepe Üniversitesi Edebiyat Fakültesi Dergisi, 19(2): 217-233.

Fielding, K.S, Terry, D.J, Masser, B.M, Hogg, M.A. 2008. Integrating social identity theory and the theory of planned behavior to explain decisions to engage in sustainable agricultural practices. British Journal of Social Psychology, 47: 23-48.

Garforth, C., Rehman, T., McKemey, K., Tranter, R., Cooke, R., Yates, C., Park, J., Dorward, P. 2004. Improving the design of knowledge transfer strategies by understanding farmer attitudes and behavior. Journal of Farm Management, 12(1): 17-32.

GTHB. 2015. Çiftçi Kayıt Sistemi Veritabanı. Gıda, Tarım ve Hayvancılık Bakanlığı, il Müdürlüğü, Hatay.

Hattam, C. 2006. Adopting organic agriculture: An investigation using the theory planned behaviour. Agricultural Economics Conference, Gold Coast, Australia, August 12-18.

https://ideas.repec.org/p/ags/iaae06/252 69.html Access date: 11.06.2016.

Kaimowitz, D. 1990. Making The Link, Agricultural Research and Technology Transfer in Developing Countries. Published in Cooperation with The International Service for National Agricultural Research (ISNAR), Westview Press, London.

Karami, E., Mansoorabadi, A. 2008. Sustainable agricultural attitudes and behaviors: a gender analysis of Iranian farmers. Environment, Development and Sustainability, 10: 883-898.

Kızılaslan, N., Ünal, Y. 2013. Çiftçilerin tarımsal yayım farkındalıklarının belirlenmesi (Tokat/Erbaa örneği). Gaziosmanpaşa Üniversitesi, Fen Bilimleri Enstitüsü Bilimsel Araştırma Dergisi, Sayı: 5, 1-9.

Kızılaslan, N. 2009. Çiftçilerin tarımsal yayım konusundaki tutum ve davranışları (Tokat ili Yeşilyurt ilçesi araştırması). Tubav Bilim Dergisi, 2(4): 439-445.

Kızılaslan, N. 1999. Tarımsal kalkınma sürecinde teknik eleman ve çiftçi eğitiminin önemi. Ziraat Mühendisliği Dergisi, Sayı: 322, s.2932.

Lam, S. 2006. Predicting intention to save water: Theory of planned behaviour, Response efficacy, vulnerability, and perceived efficiency of alternative solutions. Journal of Applied Social Psychology, 36(11): 28032824.

Lees, J.W. 1991. More Than Accountability: Evaluating Agricultural Extension Programs. The Rural Development Centre, University of New England, Armidale.

Lynne, G.D., Casey, C.F., Hodges, A., Rahmani, M. 1995. Conservation technology adoption decisions and the theory of planned behavior. Journal of Economic Psychology, 16: 581-598.

Marsh, S.P., Pannell, D.J., Lindner, R.K. 2000. The impact of agricultural extension on 
adoption and diffusion of lupins as a new crop in Western Australia. Australian Journal of Experimental Agriculture, 40: 571-583.

Nocella, G, Boecker, A., Hubbard, L., Scarpa, R. 2012. Eliciting consumer preferences for certified animal-friendly foods: Can elements of the theory of planned behavior improve choice experiment analysis? Psychology and Marketing, 29(11): 850-868.

Özçatalbaş, O., Mansuroğlu, S., Ceylan, I.C., Akçaöz, H., Kutlar, i. 2010. The evaluation of the importance of rural tourism extension for community development and Turkey. Journal of Food, Agriculture \& Environment, 8(3-4): 973-975.

Özkaya, T., Ceylan, i.Ç., Aktaş, Y., Şelli, F., Pezikoğlu, F. 2005. Tarımsal yayım hizmetleri ve organizasyonu. Türkiye Ziraat Mühendisliği, VI: Teknik Kongresi, TMMOB Ziraat Mühendisleri Odası, 2. Cilt, Ankara.

Pannell, D.J., Marshall, G.R., Barr, N.F., Vanclay, F. 2006. Understanding and promoting adoption of conservation practices by rural landholders. Australian Journal of Experimental Agriculture, 46: 1407-1424.

Pokorny, B., Cayres, G., Nunes, W. 2005. Participatory extension as basis for the work of rural extension services in the Amazon. Agriculture and Human Values, 22: 435-450.

Pouta, E., Rekola, M. 2001.The theory of planned behavior in predicting willingness to pay for abatement of forest regeneration. Society and Natural Resources, 14: 93-106.

Rehman, T., McKemey, K., Yates, C.M, Cooke, R.J., Garforth, C.J., Tranter, R.B., Park, J.R, Dorward, P.T. 2007. Identifying and understanding factors influencing the uptake of new technologies on dairy farms in SW England using the theory of reasoned action. Agricultural Systems, 94: 281-293.

Seçer, A. Emeksiz, F. 2012. Doğu Akdeniz Bölgesi'nde zeytin ve zeytinyağı üretimi, pazarlaması ve bölgede zeytinciliği geliştirme olanakları. Tarımsal Ekonomi ve
Politika Geliştirme Enstitüsü, Yayın No: 206, Ankara.

Sharifzadeh, M., Zamani, Gh.H., Khalili, D., Karami, E. 2012. Agricultural climate information use: An application of the planned behavior theory. Journal Agricultural Science and Technology, Vol. 14: 479-492.

Sjoberg, S., Kim, K., Reicks, M. 2004. Applying the theory of planned behavior to fruit and vegetable consumption by older adults. Journal of Nutrition for the Elderly, 23(4): 35-46.

Tarrant, M.A., Cordell, H.K. 1997. The effect of respondent characteristics on general environmental attitude-behavior correspondence. Environment and Behavior, 29: 618-637.

Tutkun, A., Lehmann, B. 2006. Explaining the conversion to particularly animal-friendly stabling system of farmers of the Obwalden Canton, Switzerland - Extension of the theory of planned behavior within a structural equation modeling approach. Annual Conference of the Agricultural Economics Society (AES), 30-31 March, Paris-Grigon.

https://ideas.repec.org/p/ags/ethscp/241 46.html Access date: 10.06.2016.

TüiK, 2016. Bitkisel Üretim İstatistikleri Veritabanı. Türkiye İstatistik Kurumu. https://biruni.tuik.gov.tr/bitkiselapp/bitkis el.zul Erişim tarihi: 15.06.2016.

Wauters, E., Bielders, C., Poesen, J., Govers, G., Mathijs, E. 2010. Adoption of soil conservation practices in Belgium: An examination of the theory of planned behaviour in the agri-environmental domain. Land Use Policy, 27: 86-94.

Yalçın, M., Boz, ì. 2007. Kumluca ilçesinde seralarda üreticilerin kullandıkları bilgi kaynakları. Bahçe Dergisi, 36(1-2): 1-10.

Yamane, T. 1991. Temel Örnekleme Yöntemleri. (Çevirenler: Esin, A., Aydın, C., Bakır, M.A., Gürbüzsel, E.), Literatür Yayınları: 53, İstanbul. 